\title{
Species-specific differences in
} water uptake depth of mature

\section{temperate trees vary with water availability in the soil}

\author{
Journal Article \\ Author(s): \\ Brinkmann, Nadine; Eugster, Werner (D); Buchmann, Nina (D); Kahmen, Ansgar \\ Publication date: \\ 2019-01 \\ Permanent link: \\ https://doi.org/10.3929/ethz-b-000299738
}

Rights / license:

$\underline{\text { In Copyright - Non-Commercial Use Permitted }}$

Originally published in:

Plant Biology 21(1), https://doi.org/10.1111/plb.12907

Funding acknowledgement:

136295 - iTREE-Long-term variability of tree growth in a changing environment - identifying physiological mechanisms using stable $\mathrm{C}$ and $\mathrm{O}$ isotopes in tree rings. (SNF) 
DR. NADINE BRINKMANN (Orcid ID : 0000-0002-6824-3290)

Article type : Research Paper

handling Editor: Dr. S Pfautsch

Species-specific differences in water uptake depth of mature temperate trees vary with water availability in the soil

\author{
Nadine Brinkmann ${ }^{\mathrm{a}, \mathrm{b}}$, Werner Eugster ${ }^{\mathrm{a}}$, Nina Buchmann ${ }^{\mathrm{a}}$, Ansgar Kahmen ${ }^{\mathrm{b}}$ \\ ${ }^{a}$ Department of Environmental System Sciences, ETH Zurich, Switzerland \\ ${ }^{\mathrm{b}}$ Department of Environmental Sciences - Botany, University Basel, Switzerland
}

*Corresponding author: ansgar.kahmen@unibas.ch, phone: +41 6120735 71, fax: +41 61207

2980

Running head: water uptake depth of trees varies with water availability in the soil

Key-words Acer pseudoplatanus, Fagus sylvatica, Fraxinus excelsior, Picea abies, stable water isotopes, temperate species, water uptake depth

This article has been accepted for publication and undergone full peer review but has not been through the copyediting, typesetting, pagination and proofreading process, which may lead to differences between this version and the Version of Record. Please cite this article as doi: $10.1111 / \mathrm{plb} .12907$ 


\section{Abstract}

(1) Temperate tree species differ in their physiological sensitivity to declining soil moisture and drought. Although species-specific responses to drought have often been suggested to be the result of different water uptake depths, empirical evidence for such a mechanism is scarce.

(2) Here we test if differences in water uptake depths can explain previously observed speciesspecific physiological responses of temperate trees to drought and if the water uptake depth of different species varies in response to declining soil moisture. For this purpose, we employed stable oxygen and hydrogen isotopes of soil- and xylem water that we collected over the course of three growing seasons in a mature temperate forest in Switzerland.

(3) Our data show that all investigated species utilize water from shallow soil layers during times of sufficient soil water supply. However, Fraxinus excelsior, Fagus sylvatica and Acer pseudoplatanus were able to shift their water uptake to deeper soil layers when soil water availability decreased in the top soil. In contrast, Picea abies, was not able to shift its water uptake to deeper soil layers.

(4) We conclude from our data that more drought resistant tree species are able to shift their water uptake to deeper soil layers when water availability in the top soil is becoming scarce. In addition, we were able to show that water uptake depth of temperate tree species is a trait with high plasticity that needs to be characterized across a range of environmental conditions.

\section{Introduction}

Forests are predicted to experience an increased frequency and intensity of drought events as a consequence of the changing climate (CH2011, 2011; Della-Marta et al., 2007; Schaer et al., 2004; Seneviratne et al., 2012). Water is, however, a key resource for physiological processes in trees such as transpiration, photosynthesis and growth. Drought-induced reduction of water availability for trees can thus impair physiological processes in trees and - in extreme cases - lead to desiccation (and/or 
carbon starvation) and tree death (Breda et al., 2006; Granier et al., 2007; Volkmann et al., 2016; Williams et al., 2013).

Physiological responses of temperate trees to declining soil moisture and drought have been shown to differ largely among species. For example, Hoelscher et al. (2005) found that sap flow density of Tilia cordata, Fagus sylvatica, Acer pseudoplatanus and Carpinus betulus responds more sensitively to declining soil moisture than sap flow density of Fraxinus excelsior. Similar speciesspecific responses for temperate trees have also been found for Picea abies and Betula pendula (Gartner et al., 2009), F. sylvatica, C. betulus and Quercus petraea (Leuzinger et al. (2005) and F. sylvatica, P. abies, A. pseudoplatanus, and F. excelsior (Brinkmann et al. (2016). In summary, these studies have clearly demonstrated that some temperate tree species respond particularly sensitive in their water relations to declining soil moisture or drought periods, while other species are hardly affected, even after prolonged periods without precipitation.

Different responses of different temperate tree species to declining soil moisture have - at least partly - been explained by different soil water uptake depths of the different species. Species with a deep rooting system are supposed to have access to deep and abundant soil water even during dry spells, while species with a shallow rooting system seem to experience the lack of moisture availability in the soil much earlier (Leuzinger et al., 2005; Zapater et al., 2013).

An useful approach to estimate soil water uptake depth of trees builds on the naturally occurring variability of stable isotope ratios of oxygen $(\mathrm{O})$ and hydrogen $(\mathrm{H})$ in soil and xylem water (Meinzer et al., 1999; White et al., 1985). Previous studies have shown that with a few exceptions (e.g. Ellsworth and Williams (2007); Lin and Sternberg (1994)), no fractionation occurs during water uptake via roots (Allison et al., 1984; Dawson \& Ehleringer, 1991; Wershaw et al., 1966). Given sufficient gradients in soil water $\delta^{18} \mathrm{O}$ and $\delta^{2} \mathrm{H}$ with soil depth, a comparison of soil water $\delta^{18} \mathrm{O}$ and $\delta \mathrm{H}$ values with those of xylem water allows estimating the soil water uptake depth of a tree (Dawson \& Ehleringer, 1991; Ehleringer \& Dawson, 1992; White et al., 1985). 
The few existing studies that have estimated soil water uptake depth of temperate tree species with stable isotopes have reported soil water uptake depths that indeed vary among species. Bishop and Dambrine (1995) found for example soil water uptake depths of $0.03 \mathrm{~m}$ for P. abies, whereas Pinus sylvestris was relying on water from 0.11-0.13 m soil depth. In another study, $F$. sylvatica and Tilia $s p$. took up water from 0.3-0.5 m soil depth, whereas Fraxinus excelsior took up water from 0.2-0.7 $\mathrm{m}$ soil depth (Meissner et al., 2012). What complicates the interpretation of these water uptake depths in the context of a tree's physiological sensitivity to declining soil moisture is the fact that recent studies have suggested that water uptake depths of temperate but also other tree species can be quite variable and depend on community structure, tree size, soil water potential or the time in the growing season (Asbjornsen et al., 2008; Gaines et al., 2016; Meissner et al., 2012; Plamboeck et al., 1999). F. sylvatica, Tilia sp., and F. excelsior have for example been shown to adjust their mean water uptake depth in mixed stands versus monocultures (Meissner et al., 2012). In addition, P. sylvestris has been suggested to shift its water uptake to deeper soil layers when soil water potential declined under artificial drought in a rain exclusion experiment (Plamboeck et al., 1999). Also, Asbjornsen et al. (2008) suggested that the water uptake depth varies throughout the growing season of the north American oak Quercus alba and Gaines et al. (2016) found a trend towards a deeper soil water uptake depth with increasing diameter at breast height in a mixed-hardwood forest in central Pennsylvania.

Given the indications of a variable water uptake depth for some tree species, we hypothesize that the physiological sensitivity of temperate tree species to declining soil moisture and drought does not necessarily depend on a consistent uptake of water from deep soil layers but rather on the ability of a species to shift its water uptake to deeper soil layers when moisture in the top soil becomes scarce. To test our hypothesis, we employed the natural variability of stable oxygen and hydrogen isotopes in soil and xylem water to determine the soil water uptake depths of four common European tree species (F. sylvatica, A. pseudoplatanus, F. excelsior, and P. abies) over a study period of three years. In a previous study, we have shown that the water relations of these species differ substantially in their sensitivity to declining soil moisture. By using changes in relative sap-flow rates as an 
indicator for the stomatal control of transpiration and as a proxy for the sensitivity of a species' water relations, we showed that sap flow responded most sensitively in $P$. abies followed by $F$. sylvatica, $A$. pseudoplatanus, and F. excelsior. Here we now test if the species that responded sensitively in their physiology to declining soil moisture depend entirely on water uptake from shallow soil layers and if species that are more drought resistant can shift their water uptake to deeper soil layers when moisture in the top soil declines.

\section{Materials and methods}

Study site

We conducted our research at the research site Lägeren, which is situated in the township Wettingen, Switzerland $\left(47^{\circ} 28^{\prime} 42.0^{\prime \prime} \mathrm{N}, 8^{\circ} 21^{\prime} 51.8^{\prime \prime} \mathrm{E}\right)$. It is located at $682 \mathrm{~m}$ a.s.l. on a south-facing slope at the transition from the Swiss Plateau to the Swiss Jura Mountains. The most common bedrocks are limestone and marl, starting $0.6-1 \mathrm{~m}$ below soil surface. The main soil types are rendzic leptosols (or rendzinas) and haplic cambisols (Heim et al., 2009). Mean annual precipitation is $1110 \mathrm{~mm}$ (MeteoSwiss stations Dietikon and Otelfingen) and mean annual air temperature is $9.4^{\circ} \mathrm{C}$ (MeteoSwiss stations Zürich Reckenholz and Zurich/Fluntern) (reference period: 1981-2010). The vegetation of the study site is a mature mixed forest, with tree ages ranging from 105 to 185 years. The overstory mainly consists of F. sylvatica with the companion species $P$. abies, F. excelsior, A. alba Mill. and A. pseudoplatanus (Eugster et al., 2007).

\section{Sample collection}

Volumetric soil moisture was measured with dielectric soil moisture probes (Decagon ECH2O EC-20, Pullman, WA, USA) at $0.1 \mathrm{~m}(\mathrm{n}=1), 0.2 \mathrm{~m}(\mathrm{n}=1)$ and $0.3 \mathrm{~m}(\mathrm{n}=1)$ soil depths and was recorded with a with data logger (CR1000, Campbell Scientific Inc., Logan, UT, USA) at 10-min resolution throughout the study (2012-2014). We averaged volumetric soil moisture over all soil depths as all 
probes responded to changes in water availability at the same time. Additionally, we calculated averaged daily soil moisture values that we used in the relationships with water uptake depth. The same procedure was used in (Brinkmann et al., 2016) and therefore allows a direct comparison of results from this and the previous study.

We installed five precipitation samplers at the site from 2012 to 2014 to collect throughfall precipitation for stable isotope analyses. The samplers were buried in the soil to ensure precipitation samples remained cool (Prechsl et al., 2015). Precipitation that had accumulated in the samplers was collected approximately every month. Samples were then put in $1.5 \mathrm{ml}$ airtight glass vials (MachereyNagel GmbH, Düren, Germany) and stored cool for further isotope analysis.

From 2012 to 2014, we collected soil samples five to nine times per year and across the study plot which was about 1 ha in size. At each sampling date, six soil cores were taken randomly to a depth of $70 \mathrm{~cm}$ using a Pürkhauer soil corer with a diameter of $28 \mathrm{~mm}$ (Goecke GmbH \& Co. KG, Schwelm, Germany). The soil cores were divided into eight different soil depths $(0-0.05 \mathrm{~m}, 0.05-0.1$ $\mathrm{m}, 0.1-0.2 \mathrm{~m}, 0.2-0.3 \mathrm{~m}, 0.3-0.4 \mathrm{~m}, 0.4-0.5 \mathrm{~m}, 0.5-0.6 \mathrm{~m}, 0.6-0.7 \mathrm{~m})$. Soil samples from each section were sampled and stored in $10 \mathrm{ml}$ airtight Exetainers (Labco, England) and stored on ice in the field until they were stored in a freezer at $-23^{\circ} \mathrm{C}$ prior to soil water extraction.

To determine the isotopic composition of xylem water, we collected twig samples in the tree canopy on each sampling date with the help of tree climbers. Twigs were about $1.0-1.5 \mathrm{~cm}$ in diameter. We sampled two species $(F$. sylvatica $(\mathrm{n}=4)$ and $P$. abies $(\mathrm{n}=4))$ in 2012 and four species (F. sylvatica $(\mathrm{n}=4), P$. abies $(\mathrm{n}=4), F$. excelsior $(\mathrm{n}=2)$ and $A$. pseudoplatanus $(\mathrm{n}=2))$ in 2013-2014. Samples for deciduous tree species were only collected during the growing season, i.e. after leaf flush and before leaf fall. The bark and phloem were manually removed from a twig sample and the remaining xylem samples were transferred into $10 \mathrm{ml}$ airtight Exetainers (Labco, England) and stored on ice in the field and at $-23^{\circ} \mathrm{C}$ in the lab until water extraction. Samples were collected from four directions in the canopy (north, east, south, west) in 2012 and 2013 and two directions (south, west) in 2014. Since we did not find any significant differences in xylem water $\delta^{18} \mathrm{O}$ or $\delta^{2} \mathrm{H}$ values among the 
four directions in the canopy, we averaged the values from the four directions on each sample data to a single value that we used for our calculations of soil water uptake depth.

\section{Cryogenic water extraction}

We extracted the water of soil and xylem samples using a cryogenic water line after Ehleringer et al. (2000). Soil and xylem samples in glass Exetainers were submerged in an $80^{\circ} \mathrm{C}$ water bath. Evaporated water was collected in U-tubes, which were submerged in liquid nitrogen $\left(-197^{\circ} \mathrm{C}\right)$. We extracted soil and xylem water for two hours under a vacuum of $c .0 .03 \mathrm{hPa}$. After the extraction, the U-tubes were removed, sealed and the extracted water therein was allowed to thaw, collected and stored in $1.5 \mathrm{ml}$ airtight glass vials (Macherey-Nagel GmbH, Düren, Germany) until isotope analysis.

\section{Isotope analysis}

All samples were analyzed for both $\delta^{18} \mathrm{O}$ and $\delta^{2} \mathrm{H}$ using a high-temperature conversion/elemental analyzer (TC/EA; Finnigan MAT, Bremen, Germany) that was linked to a Delta Plus XP isotope ratio mass spectrometer via a ConFlo III interface (Finnigan MAT; Werner et al. (1999)) following the carbon reduction method by Gehre et al. (2004). Water was automatically injected with a GC PAL autosampler (CTC, Zwingen, Switzerland). We followed the concept of Werner and Brand (2001) in positioning the samples and the laboratory standards providing an identical treatment for all $\delta^{18} \mathrm{O}$ and $\delta \mathrm{H}$ measurements. In addition, all post-run offline calculations (i.e., offset, memory effect and drift corrections) were carried out according to Werner and Brand (2001). Our long-term quality control lab standard water (WP-0503-Z0010B) was $0.17 \%$ for $\delta^{18} \mathrm{O}$ and $0.48 \%$ for $\delta^{2} \mathrm{H}$. All samples were referenced to the internationally accepted Vienna Standard Mean Ocean Water (V-SMOW). 


\section{Calculation of water uptake depth}

Different algorithms and statistical approaches exist to estimate soil water uptake depths of plants from the stable isotope composition of soil- and xylem water. These are either based on a linear approach (Bishop \& Dambrine, 1995; Dawson, 1993; Ehleringer et al., 1991; Meinzer et al., 1999; Walker \& Richardson, 1991; White et al., 1985), or a mixing model based approach modified for calculating water uptake depths such as done by Phillips and Gregg (2003) or Parnell et al. (2010). The approaches differ in the type of information they deliver. While the linear approach provides a distinct water uptake depth, the mixing model approach provides the proportion that water has been taken up by the tree from different soil depths (Prechsl et al., 2015). In this study, we used the linear approach and the mixing model approach developed by Parnell et al. (2010) to calculate water uptake depths.

The linear approach assumes that soil water uptake depth can be calculated by a direct comparison of $\delta^{18} \mathrm{O}$ and $\delta^{2} \mathrm{H}$ values of xylem water with the respective values of soil water. The strength of this approach (but at the same time its biggest weakness) is that it delivers a distinct soil water uptake depth but does not consider a potential mixing of water from different soil depths in the xylem. For the study we present here, we first had to linearly interpolate $\delta^{18} \mathrm{O}$ and $\delta^{2} \mathrm{H}$ values of soil water between the measured values at 8 different depths to establish continuous soil profiles for both elements. With each element, we then calculated the approximate soil water uptake depth for each individual tree by relating a given xylem water $\delta^{18} \mathrm{O}$ or $\delta^{2} \mathrm{H}$ value to the corresponding soil water $\delta^{18} \mathrm{O}$ or $\delta^{2} \mathrm{H}$ value along the soil profile. As each soil water $\delta^{18} \mathrm{O}$ or $\delta^{2} \mathrm{H}$ value corresponds to a soil depth, it was consequently possible to identify the soil water uptake depth of a tree at a given sampling date. For the analyses, we averaged water uptake depth values for each species and for each sampling date (F. sylvatica: $\mathrm{n}=4$, A. pseudoplatanus: $\mathrm{n}=2, F$. excelsior: $\mathrm{n}=2, P$. abies: $\mathrm{n}=4$ ). It was not possible to calculate soil water uptake depth for each species at all sampling dates with the linear approach because xylem water $\delta^{2} \mathrm{H}$ and $\delta^{18} \mathrm{O}$ values sometimes fell out of the range of values that we determined along the soil profile. These dates are reported in the Supporting Information. 
To calculate the proportion of soil water taken up from different soil layers we employed a mixing model approach and used the program "Stable Isotope Analysis in R" (SIAR) developed by Parnell et al. (2010). SIAR is able to solve mixing models for stable isotopic data and allows to estimate the proportion of soil water being taken up from a certain soil depth. SIAR is based on a Dirichlet distribution treating each source (i.e., soil water isotope values at different depths) independently and requires at the same time a summation to unity (Parnell et al., 2010). The model fitting itself is done using the Markov chain Monte Carlo (MCMC) approach. As the mixing model approach works best when the 'sources' are distinguishable from each other, we pre-selected the three different soil depths for our calculations where isotope differences in the soil water were the largest throughout the study period $(0-0.05 \mathrm{~m}, 0.3-0.4 \mathrm{~m}, 0.5-0.6 \mathrm{~m})$. These depths are also in the same range as the water uptake depths detected for the four species with the linear model. To determine this, we averaged the soil water isotope composition for each soil depth over the whole study period and chose the three soil depths that differed most from each other. In the actual calculation of water uptake proportions we used the $\delta^{18} \mathrm{O}$ and $\delta^{2} \mathrm{H}$ values and their standard deviation of soil water as 'sources' and $\delta^{18} \mathrm{O}$ and $\delta^{2} \mathrm{H}$ values of xylem water as 'consumers' that were obtained on the individual sampling dates. Our model parameters were set with the Trophic Enrichment Factor (TEF) $=0$, as no fractionation during water uptake via roots is assumed (Allison et al., 1984; Dawson \& Ehleringer, 1991; Wershaw et al., 1966), concentration dependence $($ concdep $)=0$, iterations $=500$ '000, and a burnin of $50^{\prime} 000$, which is the number of initial iterations to discard. The mixing model was run with both isotopes at the same time and for each species and individual separately. Due to the MCMC fitting algorithm, we get slightly different results for each run with the same dataset. To resolve this, we bootstrapped (100 times) the generated mode values of our model output for each individual tree, using an ordinary resampling. This then allowed us to extract the uncertainty of the SIAR model (i.e., $95 \%$ confidence interval, standard error). 


\section{Statistical analyses}

To test the effect of tree species, mean soil moisture and year of observation on soil water uptake depths calculated by the linear approach, we applied a Linear Mixed Model using the restricted maximum likelihood method (REML) for $\delta^{18} \mathrm{O}$ and $\delta^{2} \mathrm{H}$ values separately. First-order interactions among the predictors were also included in our model. We found the best model fit by using the local minimum AIC (Akaike's Information Criterion). Tree species, mean soil moisture and year of observation were treated as fixed effects, while day of year (DOY) was used as random effect against which all F-ratios were tested for significance.

To test the influence of tree species, mean soil moisture content and year of observation on the water uptake depths calculated by the Bayesian approach, we conducted a Linear Mixed Model using the REML method for each of the three pre-selected soil depths (0-0.05 m, 0.3-0.4 m, 0.5-0.6 m) individually. The minimum AIC was used to select the best model fit, which treated year of observation as random effect.

For all data processing, statistical analysis and graphics we used R 3.1.2 (R Core Team, 2014).

\section{Results}

Patterns of precipitation, soil and xylem water $\delta^{18} \mathrm{O}$ and $\delta^{2} H$

Annual precipitation in 2012, 2013 and 2014 was $966 \mathrm{~mm}, 843 \mathrm{~mm}$ and $812 \mathrm{~mm}$, respectively. Mean soil moisture content varied between 22.79 vol\% in 2012, $22.91 \mathrm{vol} \%$ in 2013 and $23.64 \mathrm{vol} \%$ in 2014. Soil moisture decreased during the summer months (June, July, August until September) in all years but in particular in 2013 (Fig. 1). 
We found strong seasonal patterns in troughfall precipitation $\delta^{18} \mathrm{O}$ and $\delta^{2} \mathrm{H}$ values throughout all three years of our study (Fig. 2). The seasonal variation in throughfall precipitation $\delta^{18} \mathrm{O}$ and $\delta^{2} \mathrm{H}$ values at our site was in strong agreement with the seasonal variation of precipitation $\delta^{18} \mathrm{O}$ and $\delta^{2} \mathrm{H}$ values at the two nearby GNIP stations Buchs/Suhr and Basel (Brinkmann et al., 2018). We also found strong seasonal trends for soil water $\delta^{18} \mathrm{O}$ and $\delta^{2} \mathrm{H}$ values. The magnitude of these trends differed, however, with soil depth, where the seasonal trend in $\delta^{18} \mathrm{O}$ and $\delta^{2} \mathrm{H}$ values declined with increasing soil depth. Xylem water $\delta^{18} \mathrm{O}$ and $\delta^{2} \mathrm{H}$ values for the four species were less variable throughout the growing season than throughfall precipitation or shallow soil water $\delta^{18} \mathrm{O}$ and $\delta^{2} \mathrm{H}$ values. In general, xylem water $\delta^{18} \mathrm{O}$ and $\delta^{2} \mathrm{H}$ values increased slightly towards the end of the growing season for all species. Throughfall precipitation, soil and xylem water $\delta^{2} \mathrm{H}$ and $\delta^{18} \mathrm{O}$ value all plot along the global meteoric water line (Fig. 3, for orthogonal regressions see Supporting Information).

On 29-Jul-2014 we observed an unusually narrow vertical profile in soil water $\delta^{18} \mathrm{O}$ and $\delta^{2} \mathrm{H}$ values (Fig. 2). This narrow soil profile was the result of a heavy rain event that occurred on July $22^{\text {nd }}$ 2014 and neutralized to a large degree the $\delta^{18} \mathrm{O}$ and $\delta^{2} \mathrm{H}$ variability along the soil profile. As it is difficult to estimate robust water uptake depths when variation of $\delta^{18} \mathrm{O}$ and $\delta^{2} \mathrm{H}$ values in soil water is insufficient, we omitted this sampling data from further analyses of soil water uptake depth.

\section{Water uptake depths calculated by the linear approach}

Soil water uptake depth varied across all species and years between $0.03 \mathrm{~m}$ and $0.62 \mathrm{~m}$ from $\delta^{18} \mathrm{O}$ inferred soil depths and $0.05 \mathrm{~m}$ and $0.72 \mathrm{~m}$ when using $\delta^{2} \mathrm{H}$ (Fig. 4). No overall seasonal trend in soil water uptake depth was found for any of the four species over the three years (Fig. 4).

We tested the influence of species, soil moisture, the interaction of species and soil moisture, year and DOY on soil water uptake depth of trees with a Linear Mixed Model separately for $\delta^{18} \mathrm{O}$ - and $\delta \mathrm{H}$-derrived values of uptake depth. We found species and the interaction of species and soil moisture to significantly affect soil water uptake depths inferred from soil- and xylem water $\delta^{18} \mathrm{O}$ and 
$\delta^{2} \mathrm{H}$ values (Tab. 1). We found no significant influence neither of year nor of DOY on the water uptake depth of the different tree species.

To further illustrate species-specific responses in soil water uptake depth to declining soil moisture, we tested the effects of soil moisture on soil water uptake depth individually for the four species with linear regressions. For $\delta^{2} \mathrm{H}$-derived soil water uptake depths we found that $A$. pseudoplatanus, F. excelsior and F. sylvatica shifted their soil water uptake to deeper soil depths with declining soil moisture while $P$. abies continued to depend on soil water uptake from shallow soil depths irrespective of declining soil moisture (Fig. 5). For $\delta^{18} \mathrm{O}$-derived soil water uptake depth only F. excelsior showed a significant shift in soil water uptake depth with declining soil moisture.

\section{Water uptake depths calculated by the mixing model approach}

Across all species, the proportion of soil water uptake from $0-0.05 \mathrm{~m}, 0.3-0.4 \mathrm{~m}$ or $0.5-0.6 \mathrm{~m}$ soil depth ranged from 0.02 to $0.63,0.16$ to 0.48 and 0.01 to 0.58 , respectively (see Supporting Information). We tested the influence of species, soil moisture, the interaction of species and soil moisture and the date (as random effect) on the proportion of the three different soil depths $(0-0.05 \mathrm{~m}$, 0.3-0.4 $\mathrm{m}, 0.5-0.6 \mathrm{~m}$ ) contributing to the water uptake of trees with three separate ANOVAs for each of the three soil depths (Tab. 2). We found that species, soil moisture and the interaction of species and soil moisture had a significant effect on the proportion of soil water uptake at $0-0.05 \mathrm{~m}$, whereas species and the interaction of species and soil moisture showed a significant effect at 0.5-0.6 $\mathrm{m}$ soil depth. No significant influence of the tested effects was found on the water uptake depth at 0.3-0.4 m. To further illustrate species-specific responses of soil water uptake depth to declining soil moisture, we directly related the proportion of water uptake of the four species and the three different soil depths to soil moisture in linear regressions. We found no indication that the proportion of soil water uptake shifts to deeper soil depths for P. abies when soil moisture declined (Fig. 6). In contrast, all other species showed trends of increasing proportion of soil water uptake from deeper soil depths and 
decreasing proportions of soil water uptake from shallow soil depths, when soil moisture declined (Fig. 6).

\section{Discussion}

Stable isotope composition of throughfall precipitation and soil water

We found seasonal patterns in throughfall precipitation $\delta^{18} \mathrm{O}$ and $\delta^{2} \mathrm{H}$ values with enriched values in summer and depleted values in winter. These signals were transferred to the soil water $\delta^{18} \mathrm{O}$ and $\delta^{2} \mathrm{H}$ values at all soil depths so that the vertical soil water isotope gradients varied in strength and direction with season (Fig. 1). In summer, soil water in shallow soil layers was ${ }^{18} \mathrm{O}$ and ${ }^{2} \mathrm{H}$ enriched and soil water in the deeper soil layers was ${ }^{18} \mathrm{O}$ and ${ }^{2} \mathrm{H}$ depleted. In the winter, these patterns were reversed (Brinkmann et al., 2018). Importantly, the isotope gradients that we detected in soil water were sufficiently strong in all years to allow estimating water uptake depths of the different investigated tree species. Interestingly, throughfall precipitation, soil and xylem water $\delta^{18} \mathrm{O}$ and $\delta^{2} \mathrm{H}$ values all plotted along the global meteoric water line. This suggests that only equilibrium fractionations derive the observed variability in $\delta^{18} \mathrm{O}$ and $\delta^{2} \mathrm{H}$ within throughfall precipitation, soil and xylem water and that evaporative $\delta^{18} \mathrm{O}$ and $\delta^{2} \mathrm{H}$ enrichment of water, e.g. at the top soil does not occur.

Species-specific differences in soil water uptake depth

Overall, the linear and the mixing model approach yielded the same range of soil water uptake depths where both models identified the upper $0-0.7 \mathrm{~m}$ as the soil depth providing most of the water to the investigated tree species. These water uptake depths are in the range of previously reported water uptake depths for P. abies (Bishop \& Dambrine, 1995; Meissner et al., 2012) as well as for $F$. excelsior and F. sylvatica (Meissner et al., 2012). No data on water uptake depth have previously been published for A. pseudoplatanus. 
Both approaches to calculate water uptake depth identified that the four investigated tree species show general differences in their water uptake depth. Most importantly our data show that species-specific differences in water uptake depth only occur when soil moisture was low (Figs. 5 \& 6). When water supply was sufficient in the top soil, all four species utilized water from the shallow soil layers and water uptake depths were indistinguishable among the four species (Fig. 4). With declining soil moisture in the top soil, however, the three deciduous tree species $F$. excelsior, $F$. sylvatica and A. pseudoplatanus were able to exploit deeper soil layers while $P$. abies was unable to shift its water uptake to deeper soil layers.

Variable water uptake depth as a function of soil moisture can be explained by a rooting system that is more extensive in the top soil so that water is mainly taken up from shallow soil layers as long as moisture is abundantly available in this layer (Alder et al., 1996; Koecher et al., 2012). The rooting system can extend, however, also into deeper soil layers from where the tree can extract moisture if the matrix potential in the upper soil becomes increasingly negative. It seems from our data that the deciduous tree species $F$. excelsior, $F$. sylvatica and A. pseudoplatanus have such a rooting system that allows the exploitation of shallow and deeper soil layers, but that the rooting system of $P$. abies restricts this species to water uptake from shallow soil layers only. Although, we had no equipment for estimating root profiles, our isotope data confirm the few existing studies that described the root profiles (Bakker et al., 2008; Leuschner et al., 2004; Meinen et al., 2009a; Schmid \& Kazda, 2001). While P. abies - one of the commercially most important tree species in Europe - has typically been referred to as a shallow rooting tree in the traditional forestry literature, we provide here the functional evidence that $P$. abies depends more than the other three investigated temperate trees on moisture that is available in shallow soil layers (Koestler et al., 1968).

Why do trees with deeper roots such as $F$. excelsior, $F$. sylvatica and A. pseudoplatanus compete for water from the shallow soil with other species? The top soil is the zone of highest microbial activity and thus nutrient supply to plants (Kreuzwieser \& Gessler, 2010). The ability of a tree to take up moisture from shallow soil layers ensures therefore that not only water but also nutrients can be taken up from shallow soil layers at times of abundant moisture supply. This also 
explains why the largest fraction of fine roots in temperate tree species can typically be found in the top soil (Meinen et al., 2009b; Vogt et al., 1996). Yet, when water availability in the top soil declines and the shallow roots are unable to extract sufficient water, the deeper roots of these species can maintain the trees' water supply from deeper soil layers so that the tree can remain physiologically active despite declining moisture in the top soil (Brinkmann et al., 2018).

Implications of different soil water uptake depths for tree water relations and forest ecology

While the physiological and anatomical mechanisms for species-specific responses of temperate trees to declining soil moisture remained previously unclear, the data we present here allow to directly link the physiological sensitivities of the investigated tree species to their water uptake depths. With declining soil moisture $F$. sylvatica, A. pseudoplatanus, and $F$. excelsior were able to shift their water uptake to deeper soil layers and to maintain as such their water relations. This explains why these species are less stringent in the stomatal downregulation of their sap flow than for example P. abies (Brinkmann et al., 2016). P. abies is unable to use water from deeper soil layers and cannot maintain its water supply at times of low top soil moisture. It is thus forced to maintain a tighter stomatal control over its water relations during dry periods (Brinkmann et al., 2016). The limited access to moisture in deeper soil layers makes the water relations of $P$. abies thus particularly vulnerable to drought events such as anticipated for the future climate of central Europe (Gartner et al., 2009). By directly linking the physiological sensitivity of different temperate tree species to declining soil moisture with their water uptake depth we are able to show that the ability of a tree to access moisture in deeper soil layers is a key requirement to remain physiologically active during times of low moisture supply in the top soil. A key finding of our study is that the water uptake depth of temperate species is not a fix species-specific trait but can vary in response to the availability of water in the soil. Our study has therefore also important implications for the recent observations that temperate forests with a diverse set of species are more productive and more resilient to disturbances when compared to species poor forests (Grossiord et al., 2014). Biodiversity effects on ecosystem 
functioning are typically explained by asynchronous physiological responses of species to environmental perturbations (Loreau \& de Mazancourt, 2008), niche complementarity among different species with respect to resource use (Loreau \& Hector, 2001), or facilitation effects among species (Cavard et al., 2011; del Rio et al., 2014; Forrester, 2014). We show here that the investigated tree species can differ with respect to their water uptake niche. Importantly, however, niche differences among different co-occurring temperate tree species with respect to water uptake depth were most clearly developed when water became limited during a growing season. This suggests that if ecological niches with respect to tree water uptake are to be characterized, it is important to consider the plasticity of the realized niches in response to environmental conditions and that niche differentiation of different tree species is characterized over an extended time period as we have done here.

Differences in the use of $\delta^{18} O$ and $\delta^{2} H$ for calculating water uptake depth

The use of either $\delta^{18} \mathrm{O}$ or $\delta^{2} \mathrm{H}$ values in the linear and of both isotopes in the mixing model calculations of soil water uptake depth produced similar overall patterns. However, we detected slight but consistent differences when using either $\delta^{18} \mathrm{O}$ or $\delta^{2} \mathrm{H}$ values in the linear calculation of soil water uptake depths. Here the use of $\delta^{18} \mathrm{O}$ typically suggests the uptake of shallower water from the soil than the use of $\delta^{2} \mathrm{H}$. Also, when $\delta^{18} \mathrm{O}$ values were used in the linear approach, A. pseudoplatanus and $F$. sylvatica did not show a significant downwards shift of water uptake with declining soil moisture (Fig. 5). Similar differences with respect to calculated water uptake depths based on the use of $\delta^{18} \mathrm{O}$ or $\delta \mathrm{H}$ values were also found in other studies (Meissner et al., 2014; Oerter et al., 2014; Watkins et al., 2013; Yang et al., 2015) and various explanations have been suggested for these differences: (i) carbonates exchanging oxygen in an equilibrium reaction with soil water which would affect soil water $\delta^{18} \mathrm{O}$ values but not soil water $\delta^{2} \mathrm{H}$ values (Meissner et al. (2014), (ii) interactions of soil water with water hydration spheres that result in an ${ }^{18} \mathrm{O}$ enrichment of bulk soil water and isotopic memory effects in soil water that differ for $\delta^{18} \mathrm{O}$ or $\delta^{2} \mathrm{H}$ values (Newberry et al. (in press); Oerter et al. (2014)), 
(iii) isotopically distinct water pools in the soil that differ for $\delta^{18} \mathrm{O}$ or $\delta^{2} \mathrm{H}$ values that are cryogenically extractable but are not accessible by plants (Brooks et al., 2010; Evaristo et al., 2016) (iv) fractionations in the xylem water that affect xylem water $\delta^{2} \mathrm{H}$ but not $\delta^{18} \mathrm{O}$ values (Zhao et al., 2016). Resolving these suggested effects and characterizing the confounding impacts on the use of soil and xylem water $\delta^{18} \mathrm{O}$ or $\delta^{2} \mathrm{H}$ values to characterize soil water uptake depth is an active field of research and beyond the scope of our study. Although we cannot explain why differences in the calculated water uptake occur, depending on the use of $\delta^{18} \mathrm{O}$ or $\delta^{2} \mathrm{H}$ values, we believe that these differences are small compared to the overall patterns and effects that we observed in our study. In fact, we employed two independent approaches, the linear and the mixing model approach, to estimate differences in water uptake depths among the four species. Overall, both approaches yielded the same range of soil water uptake depths and the same key ecological patterns, where water uptake depth differed across species as a function of soil moisture (i.e., a significant interaction between species soil moisture).

\section{Acknowledgements}

We would like to thank Dr. Roland Anton Werner and Annika Ackermann from the IsoLab Zurich for the many isotope measurements and Carla Keller, Hannes Hübner and Lilian Zihlmann for the water extractions. We would like to thank Jon Eugster for his great advice and support in statistics and the Swiss air quality network (NABEL) for the precipitation data. The study was supported by the Swiss National Foundation SINERGIA grant CRSII3_136295 "iTREE".

\section{Data Accessibility}

The data will be archived in the Grassland Sciences data archive of ETH Zürich, see: http://www.gl.ethz.ch/research/data-archive.html. For further details please contact Dr. Sabina Keller: sabina.keller(at)usys.ethz.ch. 


\section{Conflict of Interest:}

The authors declare that they have no conflict of interest.

\section{References}

Alder N.N., Sperry J.S., Pockman W.T. (1996) Root and stem xylem embolism, stomatal conductance, and leaf turgor in Acer grandidentatum populations along a soil moisture gradient. Oecologia 105:293-301.

Allison G.B., Barnes C.J., Hughes M.W., Leaney F.W.J. (1984) Effect of climate and vegetation on ${ }^{18} \mathrm{O}$ and deuterium profiles in soils. pp 105-122. Vienna: IAEA

Asbjornsen H., Shepherd G., Helmers M., Mora G. (2008) Seasonal patterns in depth of water uptake under contrasting annual and perennial systems in the Corn Belt Region of the Midwestern US. Plant and Soil 308:69-92.

Bakker M.R., Turpault M.P., Huet S., Nys C. (2008) Root distribution of Fagus sylvatica in a chronosequence in western France. Journal of Forest Research 13:176-184.

Bishop K., Dambrine E. (1995) Localization of tree water-uptake in Scots pine and Norway spruce with hydrological tracers. Canadian Journal of Forest Research-Revue Canadienne De Recherche Forestiere 25:286-297.

Breda N., Huc R., Granier A., Dreyer E. (2006) Temperate forest trees and stands under severe drought: a review of ecophysiological responses, adaptation processes and long-term consequences. Annals of Forest Science 63:625-644.

Brinkmann N., Eugster W., Zweifel R., Buchmann N., Kahmen A. (2016) Temperate tree species show identical response in tree water deficit but different sensitivities in sap flow to summer soil drying. Tree Physiology 36:1508-1519.

Brinkmann N., Seeger S., Markus W., Buchmann N., Eugster W., Kahmen A. (2018) Employing stable isotopes to determine the residence times of soil water and the temporal origin of water taken up by Fagus sylvatica and Picea abies in a temperate forest. New Phytologist 219:13001313.

Brooks J.R., Barnard H.R., Coulombe R., McDonnell J.J. (2010) Ecohydrologic separation of water between trees and streams in a Mediterranean climate. Nature Geoscience 3:100-104.

Cavard X., Bergeron Y., Chen H.Y.H., Pare D., Laganiere J., Brassard B. (2011) Competition and facilitation between tree species change with stand development. Oikos 120:1683-1695.

CH2011. (2011) Swiss Climate Change Scenarios CH2011. 
Dawson T.E. (1993) Hydraulic lift and water use by plants: implications for water balance, performance and plant-plant interactions. Oecologia 95:565-574.

Dawson T.E., Ehleringer J.R. (1991) Streamside trees that do not use stream water. Nature 350:335337.

del Rio M., Schuetze G., Pretzsch H. (2014) Temporal variation of competition and facilitation in mixed species forests in Central Europe. Plant Biology 16:166-176.

Della-Marta P.M., Haylock M.R., Luterbacher J., Wanner H. (2007) Doubled length of western European summer heat waves since 1880. Journal of Geophysical Research-Atmospheres 112:1:11.

Ehleringer J.R., Dawson T.E. (1992) Water-uptake by plants: perspectives from stable isotope composition. Plant Cell and Environment 15:1073-1082.

Ehleringer J.R., Phillips S.L., Schuster W.S.F., Sandquist D.R. (1991) Differential utilization of summer rains by desert plants. Oecologia 88:430-434.

Ehleringer J.R., Roden J., Dawson T.E. (2000) Assessing ecosystem-level water relations through stable isotope ratio analyses. In Methods in Ecosystem Science, ed. O Sala, RB Jackson, HA Mooney, R Howarth:181-198. New York: Springer. Number of 181-198 pp.

Ellsworth P.Z., Williams D.G. (2007) Hydrogen isotope fractionation during water uptake by woody xerophytes. Plant and Soil 291:93-107.

Eugster W., Zeyer K., Zeeman M., Michna P., Zingg A., et al. (2007) Methodical study of nitrous oxide eddy covariance measurements using quantum cascade laser spectrometery over a Swiss forest. Biogeosciences 4:927-939.

Evaristo J., McDonnell J.J., Scholl M.A., Bruijnzeel L.A., Chun K.P. (2016) Insights into plant water uptake from xylem-water isotope measurements in two tropical catchments with contrasting moisture conditions. Hydrological Processes 30:3210-3227.

Forrester D.I. (2014) The spatial and temporal dynamics of species interactions in mixed-species forests: From pattern to process. Forest Ecology and Management 312:282-292.

Gaines K.P., Stanley J.W., Meinzer F.C., McCulloh K.A., Woodruff D.R., et al. (2016) Reliance on shallow soil water in a mixed-hardwood forest in central Pennsylvania. Tree Physiology 36:444-458.

Gartner K., Nadezhdina N., Englisch M., Cermak J., Leitgeb E. (2009) Sap flow of birch and Norway spruce during the European heat and drought in summer 2003. Forest Ecology and Management 258:590-599.

Gehre M., Geilmann H., Richter J., Werner R.A., Brand W.A. (2004) Continuous flow ${ }^{2} \mathrm{H} /{ }^{1} \mathrm{H}$ and and ${ }^{18} \mathrm{O} /{ }^{16} \mathrm{O}$ analysis of water samples with dual inlet precision. Rapid Communications in Mass Spectrometry 18:2650-2660. 
Granier A., Reichstein M., Breda N., Janssens I.A., Falge E., et al. (2007) Evidence for soil water control on carbon and water dynamics in European forests during the extremely dry year: 2003. Agricultural and Forest Meteorology 143:123-145.

Grossiord C., Granier A., Ratcliffe S., Bouriaud O., Bruelheide H., et al. (2014) Tree diversity does not always improve resistance of forest ecosystems to drought. Proceedings of the National Academy of Sciences of the United States of America 111:14812-14815.

Heim A., Wehrli L., Eugster W., Schmidt M.W.I. (2009) Effects of sampling design on the probability to detect soil carbon stock changes at the Swiss CarboEurope site Lageren. Geoderma 149:347-354.

Hoelscher D., Koch O., Korn S., Leuschner C. (2005) Sap flux of five co-occurring tree species in a temperate broad-leaved forest during seasonal soil drought. Trees-Structure and Function 19:628-637.

Koecher P., Horna V., Beckmeyer I., Leuschner C. (2012) Hydraulic properties and embolism in small-diameter roots of five temperate broad-leaved tree species with contrasting drought tolerance. Annals of Forest Science 69:693-703.

Koestler J.N., Brückner E., Bibelriether H. (1968) Die Wurzeln der Waldbäume: Untersuchungen zur Morphologie der Waldbäume in Mitteleuropa. pp 284. Hamburg: Parey. 284 pp.

Kreuzwieser J., Gessler A. (2010) Global climate change and tree nutrition: influence of water availability. Tree Physiology 30:1221-1234.

Leuschner C., Coners H., Icke R. (2004) In situ measurement of water absorption by fine roots of three temperate trees: species differences and differential activity of superficial and deep roots. Tree Physiology 24:1359-1367.

Leuzinger S., Zotz G., Asshoff R., Koerner C. (2005) Responses of deciduous forest trees to severe drought in Central Europe. Tree Physiology 25:641-650.

Lin G.H., Sternberg L.D.L. (1994) Utilization of surface water by red mangrove (Rhizophora mangle L.) - An isotopic study. Bulletin of Marine Science 54:94-102.

Loreau M., de Mazancourt C. (2008) Species synchrony and its drivers: Neutral and nonneutral community dynamics in fluctuating environments. American Naturalist 172:48-66.

Loreau M., Hector A. (2001) Partitioning selection and complementarity in biodiversity experiments. Nature 412:72-76.

Meinen C., Hertel D., Leuschner C. (2009a) Root Growth and Recovery in Temperate Broad-Leaved Forest Stands Differing in Tree Species Diversity. Ecosystems 12:1103-1116.

Meinen C., Leuschner C., Ryan N.T., Hertel D. (2009b) No evidence of spatial root system segregation and elevated fine root biomass in multi-species temperate broad-leaved forests. Trees-Structure and Function 23:941-950. 
Meinzer F.C., Andrade J.L., Goldstein G., Holbrook N.M., Cavelier J., Wright S.J. (1999) Partitioning of soil water among canopy trees in a seasonally dry tropical forest. Oecologia 121:293-301.

Meissner M., Koehler M., Schwendenmann L., Hoelscher D. (2012) Partitioning of soil water among canopy trees during a soil desiccation period in a temperate mixed forest. Biogeosciences 9:3465-3474.

Meissner M., Koehler M., Schwendenmann L., Hoelscher D., Dyckmans J. (2014) Soil water uptake by trees using water stable isotopes $\left(\delta{ }^{2} \mathrm{H}\right.$ and $\delta{ }^{18} \mathrm{O}$ )-a method test regarding soil moisture, texture and carbonate. Plant and Soil 376:327-335.

Newberry S.L., Prechsl U.E., Pace M., Kahmen A. (in press) Tightly bound soil water introduces isotopic memory effects on mobile and extractable soil water pools. Isotopes in Environmental and Health Studies

Oerter E., Finstad K., Schaefer J., Goldsmith G.R., Dawson T., Amundson R. (2014) Oxygen isotope fractionation effects in soil water via interaction with cations $(\mathrm{Mg}, \mathrm{Ca}, \mathrm{K}, \mathrm{Na})$ adsorbed to phyllosilicate clay minerals. Journal of Hydrology 515:1-9.

Parnell A.C., Inger R., Bearhop S., Jackson A.L. (2010) Source Partitioning Using Stable Isotopes: Coping with Too Much Variation. Plos One 5

Phillips D.L., Gregg J.W. (2003) Source partitioning using stable isotopes: coping with too many sources. Oecologia 136:261-269.

Plamboeck A.H., Grip H., Nygren U. (1999) A hydrological tracer study of water uptake depth in a Scots pine forest under two different water regimes. Oecologia 119:452-460.

Prechsl U.E., Burri S., Gilgen A.K., Kahmen A., Buchmann N. (2015) No shift to a deeper water uptake depth in response to summer drought of two lowland and sub-alpine $\mathrm{C}_{3}$-grasslands in Switzerland. Oecologia 177:97-111.

R Core Team. (2014) R: A language and environment for statistical computing. Vienna, Austria.: R Foundation for Statistical Computing

Schaer C., Vidale P.L., Luthi D., Frei C., Haberli C., et al. (2004) The role of increasing temperature variability in European summer heatwaves. Nature 427:332-336.

Schmid I., Kazda M. (2001) Vertical distribution and radial growth of coarse roots in pure and mixed stands of Fagus sylvatica and Picea abies. Canadian Journal of Forest Research-Revue Canadienne De Recherche Forestiere 31:539-548.

Seneviratne S.I., N. Nicholls, D. Easterling, C.M. Goodess, S. Kanae, et al. ( 2012) Changes in climate extremes and their impacts on the natural physical environment. In: Managing the Risks of Extreme Events and Disasters to Advance Climate Change Adaptation, Cambridge University Press, Cambridge, UK, and New York, NY, USA

SIAR. https://cran.r-project.org/src/contrib/siar_4.2.tar.gz. 
Vogt K.A., Vogt D.J., Palmiotto P.A., Boon P., Ohara J., Asbjornsen H. (1996) Review of root dynamics in forest ecosystems grouped by climate, climatic forest type and species. Plant and Soil 187:159-219.

Volkmann T.H.M., Haberer K., Gessler A., Weiler M. (2016) High-resolution isotope measurements resolve rapid ecohydrological dynamics at the soil-plant interface. New Phytologist 210:839849.

Walker C.D., Richardson S.B. (1991) The use of stable isotopes of water in characterizing the source of water in vegetation. Chemical Geology 94:145-158.

Watkins J.M., Nielsen L.C., Ryerson F.J., DePaolo D.J. (2013) The influence of kinetics on the oxygen isotope composition of calcium carbonate. Earth and Planetary Science Letters 375:349-360.

Werner R.A., Brand W.A. (2001) Referencing strategies and techniques in stable isotope ratio analysis. Rapid Communications in Mass Spectrometry 15:501-519.

Werner R.A., Bruch B.A., Brand W.A. (1999) ConFlo III - An interface for high precision $\delta{ }^{13} \mathrm{C}$ and $\delta{ }^{15} \mathrm{~N}$ analysis with an extended dynamic range. Rapid Communications in Mass Spectrometry 13:1237-1241.

Wershaw R.L., Friedman I., Heller S.J. (1966) Hydrogen isotope fractionation of water passing through the trees. In Advances of organic geochemistry, ed. F Hobson, M Speers:55-67. New York: Pergamon. Number of 55-67 pp.

White J.W.C., Cook E.R., Lawrence J.R., Broecker W.S. (1985) The D/H ratios of sap in trees implications for water sources and tree-ring D/H ratios. Geochimica Et Cosmochimica Acta 49:237-246.

Williams A.P., Allen C.D., Macalady A.K., Griffin D., Woodhouse C.A., et al. (2013) Temperature as a potent driver of regional forest drought stress and tree mortality. Nature Climate Change 3:292-297.

Yang B., Wen X.F., Sun X.M. (2015) Seasonal variations in depth of water uptake for a subtropical coniferous plantation subjected to drought in an East Asian monsoon region. Agricultural and Forest Meteorology 201:218-228.

Zapater M., Breda N., Bonal D., Pardonnet S., Granier A. (2013) Differential response to soil drought among co-occurring broad-leaved tree species growing in a 15-to 25-year-old mixed stand. Annals of Forest Science 70:31-39.

Zhao L., Wang L., Cernusak L.A., Liu X., Xiao H., et al. (2016) Significant difference in hydrogen isotope composition between xylem and tissue water in Populus Euphratica. Plant Cell and Environment 39:1848-1857. 


\section{Tables}

Tab. 1: The influence of tree species, mean soil moisture (SMC) (averaged from $0.1 \mathrm{~m}, 0.2 \mathrm{~m}, 0.3 \mathrm{~m}$ ), year of observation and day of year (DOY) on water uptake depth calculated from $\delta^{18} \mathrm{O}$ and $\delta^{2} \mathrm{H}$ values by the linear approach was tested with a Linear Mixed Model over all study years. Shown are mean square, number of degrees of freedom, denominator degrees of freedom, F ratio, p-value and the significance level (with $*<0.05, * *<0.01, * * *<0.001)$.

\begin{tabular}{lllllll}
\hline Water uptake depth $\left(\boldsymbol{\delta}^{18} \mathbf{O}\right)$ & & & & & & \\
& Mean Square & NumDF & DenDF & F ratio & p-value & Sig \\
\hline Tree species & 539.82 & 3 & 125.33 & 8.7737 & $<0.001$ & $* * *$ \\
SMC & 93.35 & 1 & 11.96 & 1.5173 & 0.2417 & \\
Year & 109.99 & 2 & 10.77 & 1.7877 & 0.2136 & \\
Tree species:SMC & 449.32 & 3 & 125.73 & 7.3028 & 0.0002 & $* * *$ \\
SMC:Year & 108.18 & 2 & 10.95 & 1.7582 & 0.2177 & \\
Residual & 61.53 & & & & & \\
\end{tabular}

\section{Water uptake depth $\left(\delta^{2} \mathrm{H}\right)$}

\begin{tabular}{lllllll}
\hline & Mean Square & NumDF & DenDF & F ratio & p-value & Sig \\
\hline Tree species & 1418.53 & 3 & 112.48 & 15.3889 & $<0.001$ & $* * *$ \\
SMC & 97.98 & 1 & 11.49 & 1.0630 & 0.3237 & \\
Year & 23.08 & 2 & 10.46 & 0.2504 & 0.7831 & \\
Tree species:SMC & 921.74 & 3 & 113.00 & 9.9995 & $<0.001$ & $* * *$ \\
SMC:Year & 37.87 & 2 & 10.58 & 0.4108 & 0.6732 & \\
Residual & 92.18 & & & & & \\
\hline
\end{tabular}


Tab. 2: The influence of species, mean soil moisture content (SMC) (averaged from $0.1 \mathrm{~m}, 0.2 \mathrm{~m}, 0.3$ $\mathrm{m})$, the interaction of the two factors and date as random effect on the proportional water uptake at 0 $0.05 \mathrm{~m}, 0.3-0.4 \mathrm{~m}, 0.5-0.6 \mathrm{~m}$ soil depth, respectively calculated by the mixing model approach was tested with a Linear Mixed Model over all study years. Shown are mean square, number of degrees of freedom, denominator degrees of freedom, F ratio, p-value and the significance level (with $*<0.05$, $* *<0.01, * * *<0.001)$

Proportional water uptake at 0-0.05 m soil depth

\begin{tabular}{|c|c|c|c|c|c|c|}
\hline & Mean Square & NumDF & DenDF & F value & p-value & Sig \\
\hline Tree species & 0.03 & 3 & 32.44 & 4.8896 & 0.0065 & $* *$ \\
\hline SMC & 0.05 & 1 & 16.45 & 7.7419 & 0.0131 & $*$ \\
\hline Tree species:SMC & 0.03 & 3 & 32.88 & 3.8907 & 0.0175 & $*$ \\
\hline Residual & 0.01 & & & & & \\
\hline
\end{tabular}

Proportional water uptake at 0.3-0.4 m soil depth

\begin{tabular}{lllllll}
\hline & Mean Square & NumDF & DenDF & F value & p-value & Sig \\
\hline Tree species & 0.00 & 3 & 37.00 & 0.3367 & 0.7989 & \\
SMC & 0.01 & 1 & 18.02 & 4.2545 & 0.0539 & \\
Tree species:SMC & 0.00 & 3 & 37.48 & 0.4807 & 0.6977 & \\
Residual & 0.00 & & & & & \\
& & & & & & \\
\hline
\end{tabular}

Proportional water uptake at $0.5-0.6 \mathrm{~m}$ soil depth

\begin{tabular}{lllllll}
\hline & Mean Square & NumDF & DenDF & F value & p-value & Sig \\
\hline Tree species & 0.02 & 3 & 32.35 & 4.5361 & 0.0092 & $* *$ \\
SMC & 0.01 & 1 & 16.41 & 3.4100 & 0.0829 & \\
Tree species:SMC & 0.01 & 3 & 32.79 & 3.3218 & 0.0316 & $*$ \\
Residual & 0.00 & & & & & \\
\end{tabular}




\section{Figure legends}

Fig. 1 Daily sum of precipitation and daily mean volumetric soil moisture (at $0.1 \mathrm{~m}, 0.2 \mathrm{~m}, 0.3 \mathrm{~m}$ soil depth and mean averaged over all soil depths) measured continuously during the years 2012-2014 at the research site Lägeren, Switzerland.

Fig. 2 (a) $\delta^{18} \mathrm{O}$ and (b) $\delta^{2} \mathrm{H}$ values of throughfall precipitation at the Lägeren research site and the two GNIP stations Buchs/Suhr and Basel, of soil water at different depths and of xylem water of four tree species (A. pseudoplatanus $(\mathrm{n}=2), F$. excelsior $(\mathrm{n}=2), F$. sylvatica $(\mathrm{n}=4), P$. abies $(\mathrm{n}=4))$ across three study years (2012-2014). Shaded areas represent the main growing season: 15 May - 30 Sep.

Fig. $3 \delta^{18} \mathrm{O}$ and $\delta^{2} \mathrm{H}$ values of throughfall precipitation, soil water and xylem water of the four tree species (A. pseudoplatanus $(\mathrm{n}=2), F$. excelsior $(\mathrm{n}=2), F$. sylvatica $(\mathrm{n}=4), P$. abies $(\mathrm{n}=4))$ plotted in dual isotope space.

Fig. 4 Linear estimation of soil water uptake depth using $\delta^{18} \mathrm{O}$ and $\delta^{2} \mathrm{H}$ of soil water and xylem water of four tree species (A. pseudoplatanus $(\mathrm{n}=2), F$. excelsior $(\mathrm{n}=2), F$. sylvatica $(\mathrm{n}=4), P$. abies $(\mathrm{n}=4))$ across three study years. Shaded areas represent the main growing season: 15 May - 30 Sep.

Fig. 5 Linear relationships between the inferred water uptake depths (calculated with the linear approach using $\delta^{18} \mathrm{O}$ and $\delta^{2} \mathrm{H}$ ) and mean daily soil moisture content [vol\%] (averaged across $0.1 \mathrm{~m}$, $0.2 \mathrm{~m}, 0.3 \mathrm{~m})$ for A. pseudoplatanus $(\mathrm{n}=2), F$. excelsior $(\mathrm{n}=2), F$. sylvatica $(\mathrm{n}=4)$ and $P$. abies $(\mathrm{n}=4)$. 
Fig. 6 Linear regressions between the proportional water uptake at 0-0.05 m, 0.3-0.4 m, 0.5-0.6 m depth and mean daily soil moisture content [vol\%] (averaged across $0.1 \mathrm{~m}, 0.2 \mathrm{~m}, 0.3 \mathrm{~m}$ ) for $A$. pseudoplatanus $(\mathrm{n}=2), F$. excelsior $(\mathrm{n}=2), F$. sylvatica $(\mathrm{n}=4)$ and $P$. abies $(\mathrm{n}=4)$ during the growing season (15 May - 30 Sep). Black lines indicate highly significant $(\mathrm{p}=0.01-0.05)$ relationships between water uptake and soil moisture content, dashed lines indicate marginally significant relationships $(\mathrm{p}=0.05-0.1)$ of the linear regressions.

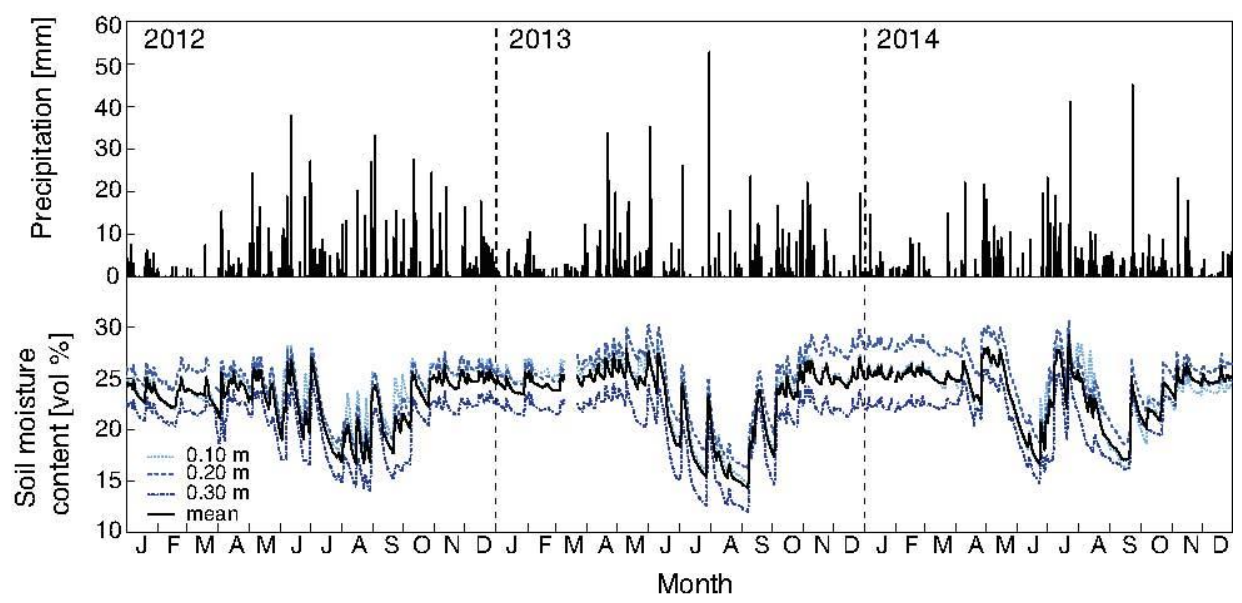



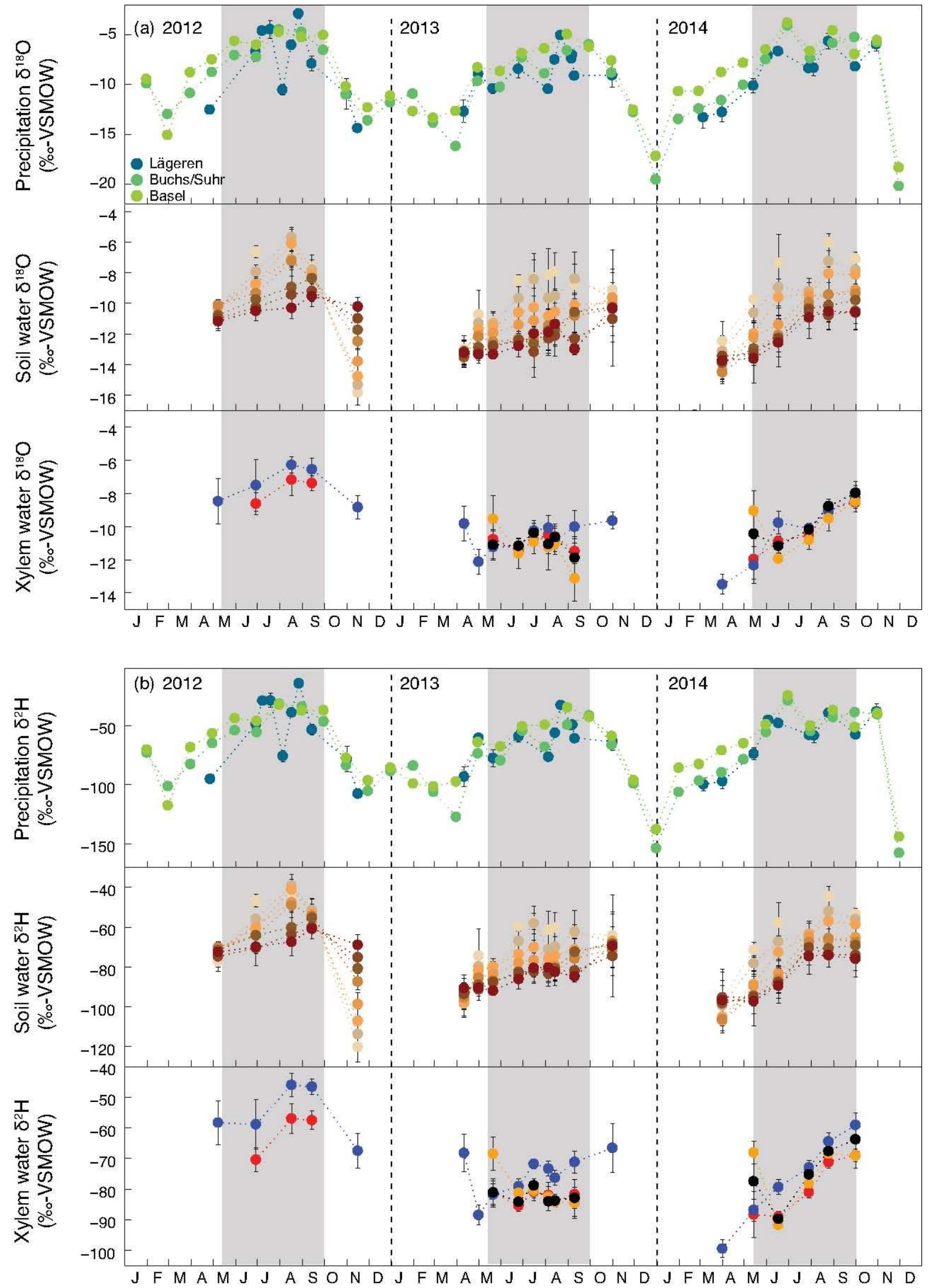

Month

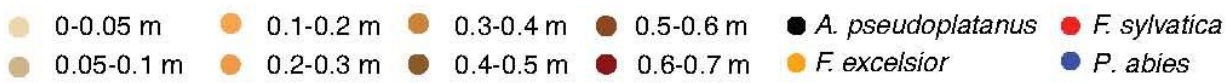



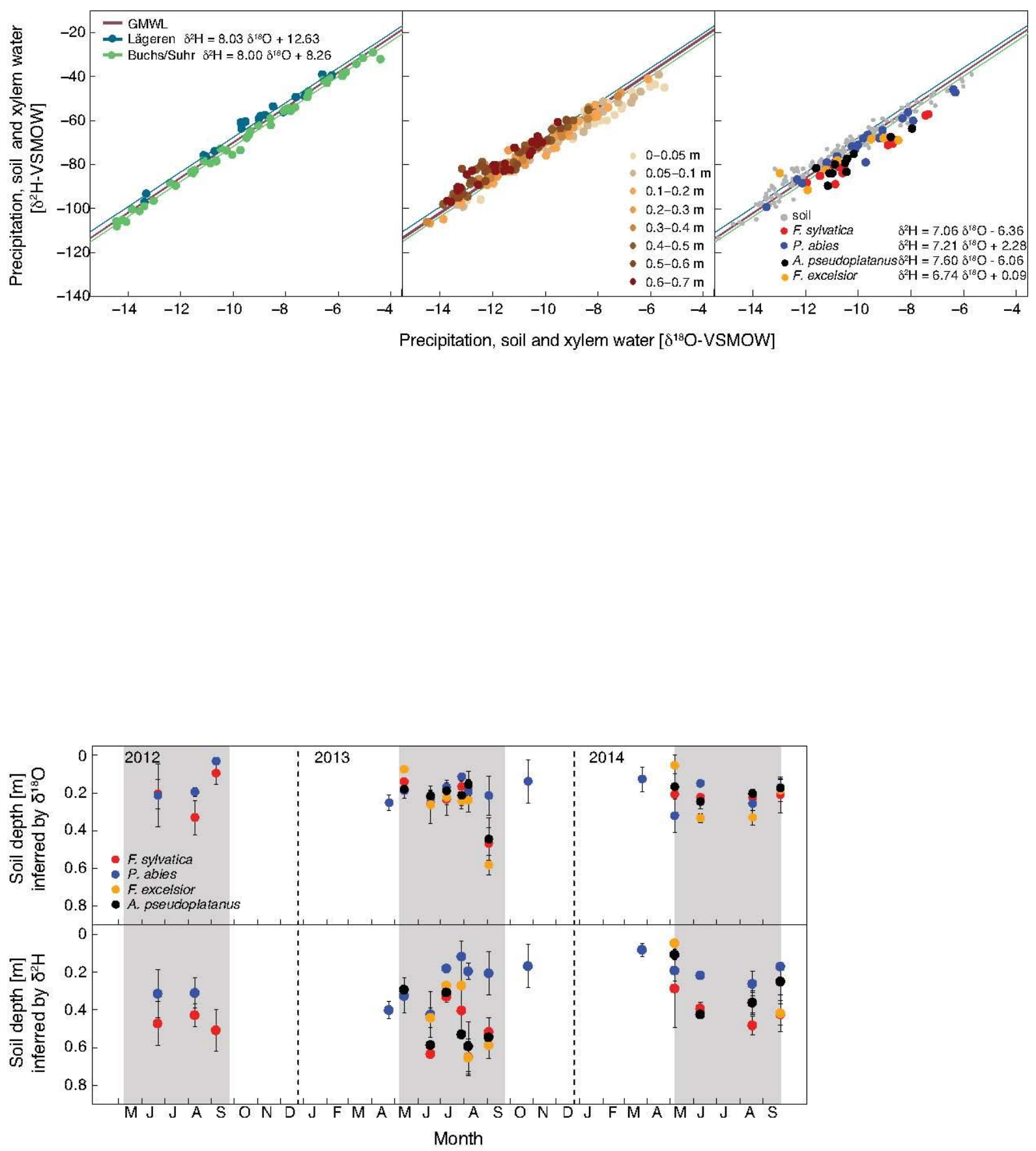

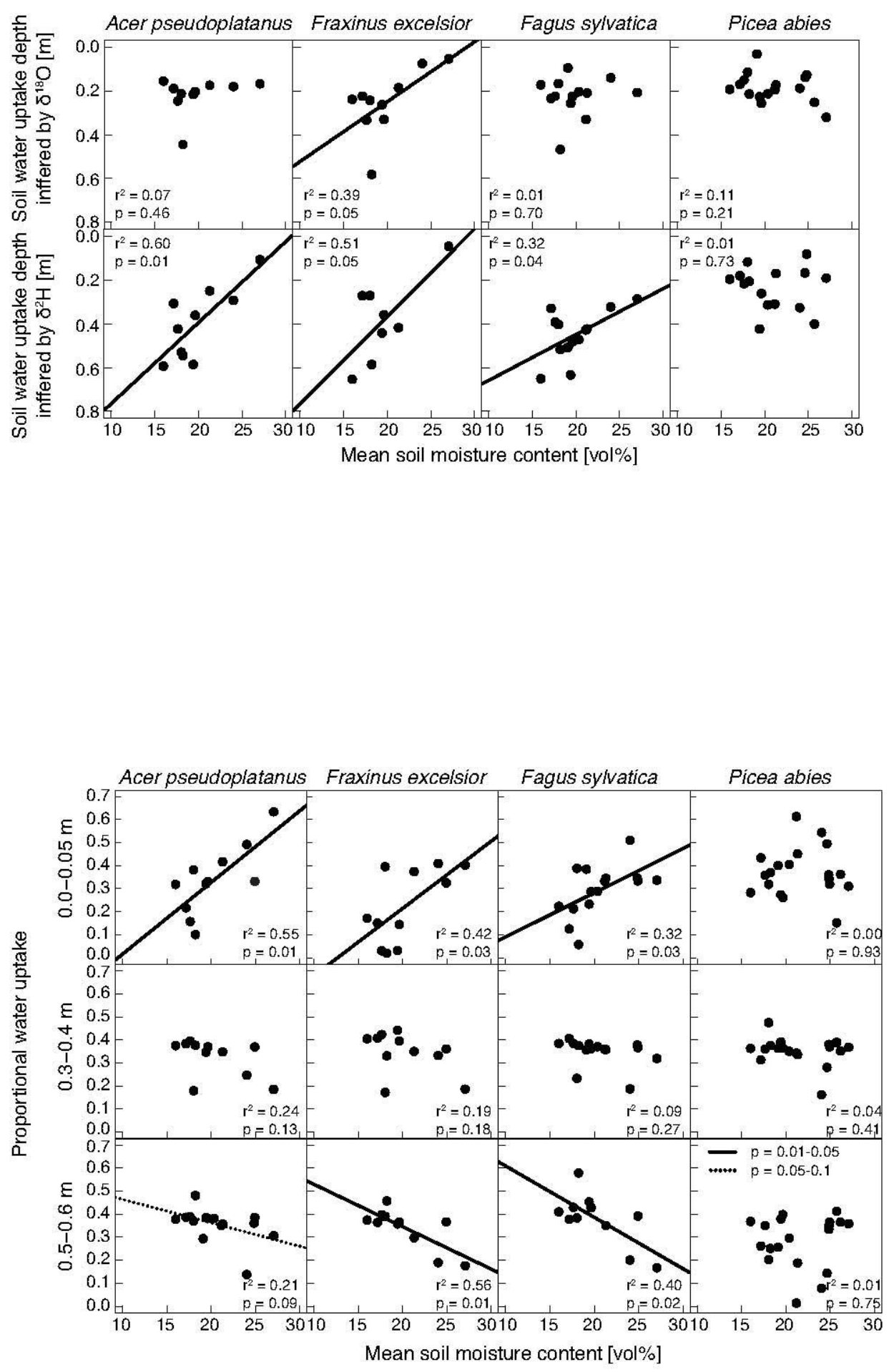